SHORT COMMUNICATION

\title{
New record of the fringed leaf frog, Cruziohyla craspedopus (Anura: Phyllomedusidae) extends its eastern range limit
}

\author{
Rafael de FRAGA ${ }^{1 *} \odot$, Kelly TORRALVO ${ }^{2}$ \\ ' Universidade Federal do Oeste do Pará - UFOPA, Programa de Pós-Graduação em Recursos Naturais Amazônicos, Av. Mendonça Furtado, 2240, Aldeia, 68040-050 \\ Santarém, Pará, Brasil \\ 2 Instituto Nacional de Pesquisas da Amazônia - INPA, Programa de Pós-Graduação em Ecologia, Av. Efigênio Sales, 2239, Aleixo, 69060-020, Manaus, Amazonas, Brasil \\ * Corresponding author: r.defraga@gmail.com; (D) https://orcid.org/0000-0002-9900-4276
}

\begin{abstract}
The fringed leaf frog, Cruziohyla craspedopus is rarely sampled in the Brazilian Amazon, probably due to low detection probability associated with its arboreal habit. The knowledge about the species' distribution stems from successive additions of occasional occurrence records, which indicate that the species is widely distributed throughout Amazonia. We present new occurrence records to update the geographic range of the species, which is hereby extended $224 \mathrm{~km}$ to the northeast. We also present morphological data from collected specimens and discuss the updated range from the geographic and ecological points of view. We show that the range of the leaf frog crosses several main tributaries along the southern bank of the Amazonas River, although the species occurrence is apparently limited by a minimum tree cover of $70 \%$.
\end{abstract}

KEYWORDS: Amazon Basin, detectability, Tapajós, tree cover

\section{Novo registro de ocorrência da perereca-franjada, Cruziohyla craspedopus (Anura: Phyllomedusidae) estende o limite oriental de sua distribuição}

\section{RESUMO}

A perereca franjada, Cruziohyla craspedopus é raramente amostrada na Amazônia brasileira, provavelmente devido à baixa probabilidade de detecção associada ao seu hábito arborícola. A distribuição geográfica conhecida da espécie é resultado da adição sucessiva de registros ocasionais de ocorrência, que indicam que ela é amplamente distribuída na Amazônia. Nós apresentamos novos pontos de ocorrência para atualizar a distribuição geográfica da espécie, estendendo-a em 224 km na direção nordeste. Nós também apresentamos dados morfológicos dos espécimes coletados e discutimos a distribuição atualizada sob pontos de vista geográfico e ecológico. Mostramos que a distribuição de pererecas franjadas cruza vários tributários da margem sul do Rio Amazonas, embora esteja aparentemente limitada por cobertura arbórea mínima de 70\%.

PALAVRAS-CHAVE: Bacia Amazônica, cobertura arbórea, detectabilidade, Tapajós

The genus Cruziohyla Faivovich, Haddad, Garcia, Frost, Campbell, and Wheeler 2005 comprises three species of moderate to large sized treefrogs, closely related to Agalychnis Cope, 1864 (Gray 2018). Among the Cruziohyla species, an impressive combination of colors, blotches, stripes and fringes makes the fringed leaf frog Cruziohyla craspedopus (Funkhouser 1957) easily distinguishable from C. calcarifer (Boulenger, 1902) and C. sylviae Gray, 2018. The species inhabits dense lowland-rainforests in Ecuador, Colombia, Peru and Brazil (Frost 2019), and photographic records (although not in formal voucher-based publications) exist for Bolivia (see <http://sernap.gob.bo/blog/la-rana-de-los- arboles-habita-en-el-madidi/> and <https://www.facebook. com/groups/172267329493705/>).

Cruziohyla craspedopus has rarely been found in anuran surveys, probably due to its arboreal habits, as sampling frogs in high plant strata depends on climbing or surveying trees from suspended platforms (Lynch 2005). Despite lack of statistical support, it has been suggested that finding $C$. craspedopus is restricted to unpredictable breeding events, when individuals migrate vertically to low strata of the understory (Hoogmoed and Cadle 1991; Block et al. 2003; Moraes and Pavan 2017). The geographical range of the species has thus been determined through the publication of 
occasional occurrence data (Rodríguez and Duellman 1994; Lima et al. 2003; Meneghelli et al. 2011; Rodrigues et al. 2011; Venancio et al. 2014; Bitar et al. 2015; Núñez et al. 2015; Moraes and Pavan 2017), which indicate that C. craspedopus is widely distributed across Amazonia (Moraes and Pavan 2017), as had been predicted by Hoogmoed and Cadle (1991).

Here we report new distribution records of C. craspedopus that extend its easternmost distribution limit on the east bank of the Tapajós River (eastern Brazilian Amazon). Additionally, we present morphological data and discuss the distribution of C. craspedopus in relation to the main rivers of the Amazon Basin and a landsat-based tree cover distribution (Sexton et al. 2013). Tree cover is thought to be an important factor affecting species distribution and connectivity, as it determines availability of foraging, resting and reproductive sites. We used the raster R-package (Hijmans 2019) to extract data on the percentage of tree cover from each geographic coordinate.

On February 6-12 2019 we found three adult females of C. craspedopus in the Tapajós National Forest (3²1'21.0"S, 54057'01.7”W, $204 \mathrm{~m}$ asl), a federal reserve covering about 527,000 ha of rainforest in the eastern Brazilian Amazon (municipality of Belterra, Pará state). The specimens were found close together (2-22 m apart), perched at about $2.5 \mathrm{~m}$ above ground in a non-floodable forest $\left(25.9^{\circ} \mathrm{C}, 93 \%\right.$ relative humidity). The perches were thin tree branches, located on the edge of a small unpaved road. Several puddles on the road were constantly used as calling and spawning sites by other frog species [e.g. Leptodactylus paraenesis Heyer, 2005; Rhinella major (Müller and Hellmich, 1936); Rhinella marina (Linnaeus, 1758); Pithecopus hypochondrialis (Daudin, 1800)], but we observed no reproductive activity of C. craspedopus. However, we found gravid females with mature oocytes, which suggests that individuals were reproductively active.

The species was identified by a combination of dark-green dorsal surface with gray-blueish irregular blotches (Figure 1a), bright-orange ventral surface (Figure $1 \mathrm{~b}$ ), vertical dark bars on a yellow background in the flanks, thighs and forearms, narrow dermal fringes on the lower jaw and on the outer edge of the forearm, and well-developed fringes on the outer edge of the tarsus (Funkhouser 1957; Hoogmoed and Cadle 1991; Gray 2018). Specimens were collected under IBAMA/SISBIO license nr. 67545-1/2019, and deposited in the herpetological collection of Universidade Federal do Oeste do Pará (UFOPA), Santarém, Pará, Brazil. Additional morphological data (based on Moraes and Pavan 2017) and voucher numbers of the specimens are provided in Table 1.

This is the first record of C. craspedopus east of the Tapajós River, which extends the species' range $224 \mathrm{~km}$ northeast from its previously known easternmost locality (Parque Nacional da Amazônia, Pará, Brazil; Moraes and Pavan 2017). The updated map (Figure 2) and locality record list (Table 2) show that the species is widely distributed throughout the Amazonian lowland- forests, crossing several of the main southern tributaries of the Amazonas River. To the north, the species is apparently limited by the Japurá River, and has not been reported north of the Amazonas River from the border between Brazil and Colombia. Biogeographic studies should focus on testing the hypothesis that the strength of the Amazonas River as a barrier to the species dispersal increases downstream. To the east, the species reaches the interfluve between the Tapajós and Iriri rivers, and possibly extends to the west bank of the Xingu River. To the west, the species is limited by the Andes, and its southernmost record lies in the Andean piedmont of Madidi National Park, Bolivia

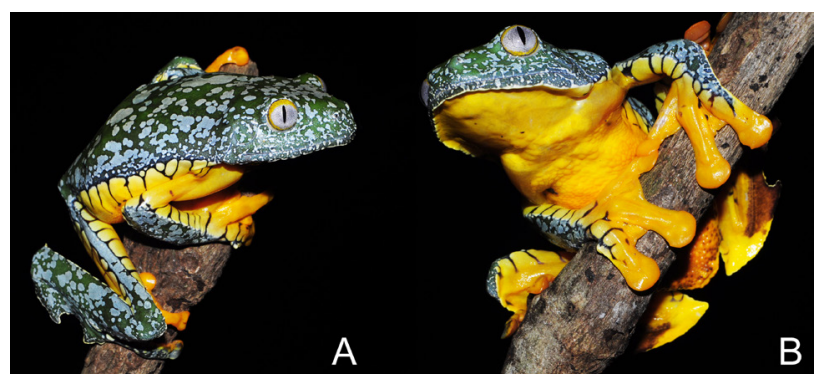

Figure 1. Dorsal $(A)$ and ventral $(B)$ views of Cruziohyla craspedopus from the Tapajós National Forest, eastern Brazilian Amazon. Female, 76.19 mm SVL, UFOPA-H 1486. This figure is in color in the electronic version.

Table 1. Morphological data ( $\mathrm{mm}$ ) of three Cruziohyla craspedopus specimens from the Tapajós National Forest, Pará, Brazil (identified by their collection voucher numbers). SVL: snout-vent length, FAL: forearm length from distal edge of hand to outer edge of flexed elbow, HA: hand length from distal edge of hand to tip of finger III, TL: tibia length from proximal edge of flexed knee to heel, FL: foot length from proximal edge of inner metatarsal tubercle to tip of Toe IV, HW: head width at level of angle of jaw, HL: head length from angle of jaw to tip of snout, ED: eye diameter, IN: internarial distance, IO: interorbital distance, EN: eye-nostril distance, TD: tympanum diameter, WFD: finger III disc width, WTD: toe IV disc width, and THL: thigh length.

\begin{tabular}{lccc}
\hline Parameter & UFOPA-H 1486 & UFOPA-H 1487 & UFOPA-H 1488 \\
\hline Sex & Female & Female & Female \\
SVL & 76.19 & 73.79 & 74.84 \\
FAL & 15.82 & 14.48 & 14.46 \\
HA & 25.69 & 24.72 & 25.36 \\
\hline TL & 41.96 & 41.65 & 40.30 \\
FL & 30.04 & 28.64 & 29.86 \\
HW & 25.15 & 23.55 & 25.12 \\
HL & 22.15 & 22.97 & 22.79 \\
\hline ED & 4.84 & 5.48 & 5.56 \\
IN & 6.80 & 7.12 & 6.68 \\
\hline IO & 19.11 & 19.06 & 19.23 \\
\hline EN & 9.23 & 8.53 & 7.32 \\
\hline TD & 4.63 & 4.31 & 5.16 \\
WFD & 5.85 & 5.60 & 5.62 \\
WTD & 4.86 & 5.12 & 4.58 \\
THL & 38.13 & 36.15 & 36.65 \\
\hline
\end{tabular}




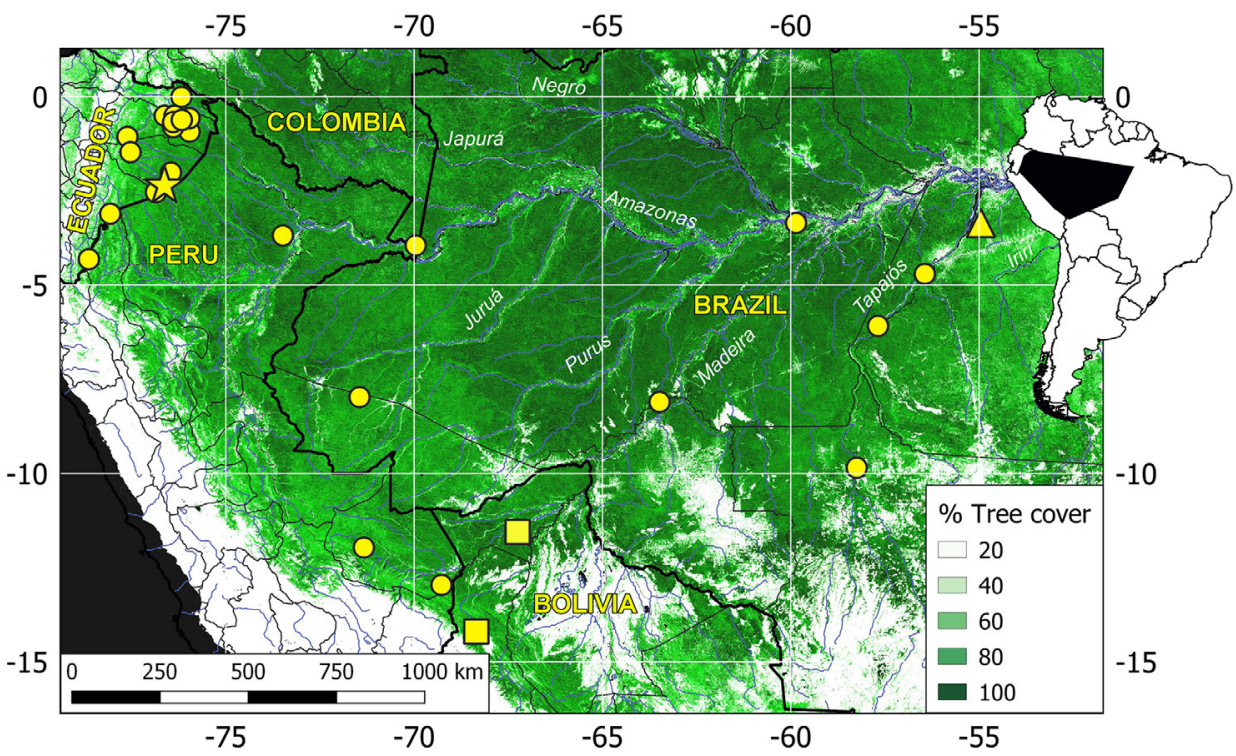

Figure 2. Updated distribution of Cruziohyla craspedopus in Amazonia. The star is the type-locality, circles are literature data, squares are photographic records reported in newsfeeds with no voucher specimens, and the triangle represents the specimens reported in this study. Locality details are in Table 2. This figure is in color in the electronic version.

Table 2. Occurrence records of Cruziohyla craspedopus in Amazonia (plotted in Figure 2). The type locality is in bold; NV = photographic records in informal nonvoucher-based electronic sources; ${ }^{*}=$ coordinates are estimates for imprecise locality reports by the author(s) of the record.

\begin{tabular}{|c|c|c|c|}
\hline Locality & Longitude & Latitude & Reference \\
\hline Kunsunts-Shuar Center, Zamora-Chinchipe, Ecuador & -78.639200 & -4.316639 & Read and Ron (2018) \\
\hline Morona-Santiago, Santiago River, Ecuador & -78.072034 & -3.110383 & Hoogmoed and Cadle (1991) \\
\hline Jatún Biological Station, Pastaza, Ecuador & -77.616000 & -1.066600 & Read and Ron (2018) \\
\hline Villano, Pastaza, Ecuador & -77.534790 & -1.476040 & Read and Ron (2018) \\
\hline Ishpingo River, Pastaza, Ecuador & -76.858330 & -2.538666 & Read and Ron (2018) \\
\hline Bobonaza River, Chicherota, Pastaza, Ecuador & -76.633000 & -2.366600 & Funkhouser (1957) \\
\hline Limoncocha, Orellana, Pastaza, Ecuador & -76.625972 & -0.507551 & Hoogmoed and Cadle (1991) \\
\hline Shiona, Pastaza, Ecuador & -76.459999 & -2.010000 & Read and Ron (2018) \\
\hline Yasuní National Park, Orellana, Ecuador & -76.401167 & -0.677166 & Read and Ron (2018) \\
\hline Cueva Boyopare, Orellana, Ecuador & -76.399511 & -0.809494 & Read and Ron (2018) \\
\hline Napo River, Sucumbíos, Ecuador & -76.364930 & -0.508680 & Read and Ron (2018) \\
\hline Cuyabeno Reserve, Sucumbíos, Ecuador & -76.181660 & -0.009700 & Read and Ron (2018) \\
\hline Tiputini Biodiversity Station, Sucumbíos, Ecuador & -76.171944 & -0.618056 & Read and Ron (2018) \\
\hline Comunidad Samona, Orelanna, Ecuador & -75.967590 & -0.571890 & Read and Ron (2018) \\
\hline Yasuní National Park, Orellana, Ecuador & -75.964000 & -0.934000 & Read and Ron (2018) \\
\hline Iquitos Region, Peru & -73.487502 & -3.684978 & Rodríguez and Duellman (1993) \\
\hline Tarauacá, Acre, Brazil & -71.451600 & -7.978100 & Venancio et al. (2014) \\
\hline Cocha Cashu Biological Station, Madre de Dios, Peru & -71.336928 & -11.970719 & Hoogmoed and Cadle (1991) \\
\hline Leticia, Amazonas, Colombia \# & -69.960314 & -3.950472 & Ruiz-Carranza et al. (1993) \\
\hline Tambopata Reserve, Madre de Dios, Peru & -69.275150 & -12.965263 & Hoogmoed and Cadle (1991) \\
\hline Madidi National Park, La Paz, Bolivia \# & -68.350051 & -14.200972 & $N V^{*}$ \\
\hline El Sena, Pando, Bolivia \# & -67.252281 & -11.555366 & $N V^{* *}$ \\
\hline Cuniã Ecological Station, Rondônia, Brazil & -63.483300 & -8.106500 & Meneghelli et al. (2011) \\
\hline Castanho, Amazonas, Brazil & -59.860500 & -3.354600 & Lima et al. (2003) \\
\hline São Nicolau Farm, Cotriguaçu, Mato Grosso, Brazil & -58.249300 & -9.854600 & Rodrigues et al. (2011) \\
\hline Jacareacanga, Pará, Brazil & -57.683100 & -6.088500 & Bitar et al. (2015) \\
\hline Amazonas National Park, Pará, Brazil & -56.441400 & -4.707700 & Moraes and Pavan (2017) \\
\hline Tapajós National Forest, Pará, Brazil & -54.950472 & -3.357500 & this study \\
\hline Tapajós National Forest, Pará, Brazil & -54.950308 & -3.357389 & this study \\
\hline Tapajós National Forest, Pará, Brazil & -54.950306 & -3.357389 & this study \\
\hline
\end{tabular}

${ }^{*}<$ http://sernap.gob.bo/blog/la-rana-de-los-arboles-habita-en-el-madidi/>;

** <https://www.facebook.com/groups/172267329493705/>) 
(Table 2, Figure 2). In Brazil, species is limited to the south by the contact zone between dense forests and Cerrado savannas and the agricultural frontier known as the arc of deforestation (Fearnside 2005). Although C. craspedopus has been classified as "Least Concern" by IUCN (Angulo et al. 2004), the southern region of its range, where accelerated habitat loss is occurring, should be prioritized for updating its conservation assessment.

Data from the landsat-based tree cover distribution showed that records of $C$. craspedopus are limited to localities with a minimum tree cover of $70 \%$ along a relatively wide altitudinal gradient $(30-1600 \mathrm{~m}$ asl). This may be related to biological traits of the species, as the use of high plant strata during non-reproductive periods (Moraes and Pavan 2017), and the reproductive dependence on the availability of water accumulated in natural (Turell et al. 2016) or artificial (Wizen 2017) reservoirs. The fact that other species with a similar requirement [e.g. Osteocephalus aff. oophagus, Trachycephalus resinifictrix (Goeldi, 1907); Lima et al. 2012] were commonly sampled visually and acoustically during our field work suggests that the lack of reproductive sites is not a limiting factor for the occurrence of $C$. craspedopus. Additionally, tadpoles and metamorphs were observed in poor-quality human-made water reservoirs, suggesting that water quality does not limit the reproduction of the species (Wizen 2017). However, even reproductive sites with poor water quality were surrounded by trees, which suggests tree cover as a major factor affecting the species' occurrence. Distribution modeling of C. craspedopus should focus on quantitative variables of vegetation structure, to explicitly test the effects of reproductive vertical migration from the canopy to the understory on detection probabilities (Hoogmoed and Cadle 1991; Block et al. 2003; Moraes and Pavan 2017), and the hypothesis that height and density of vegetation are positively correlated with frog densities.

\section{ACKNOWLEDGMENTS}

We thank Edivaldo Farias, Jony Oliveira and the COOMFLONA for field assistance. Logistics was supported by Instituto Nacional de Pesquisas da Amazônia (INPA), Centro de Estudos Integrados da Biodiversidade Amazônica (CENBAM), Programa de Pesquisas em Biodiversidade (PPBio), Universidade Federal do Oeste do Pará (UFOPA), Fundação de Amparo à Pesquisas do Estado do Amazonas (FAPEAM), and Instituto Chico Mendes para Conservação da Biodiversidade (ICMBio). Coordenação de Aperfeiçoamento de Pessoal de Nível Superior (CAPES) and FAPEAM provided scholarships to RDF and KT, respectively.

\section{REFERENCES}

Angulo, A.; Coloma, L.A.; Ron, S.R.; Hoogmoed, M.; Castro, F.; Rueda-Almonacid, J.V.; Cisneros-Heredia, D.F.; Icochea M. 2004. Cruziohyla craspedopus. The IUCN Red List of Threatened Species 2004. (http://dx.doi.org/10.2305/IUCN.UK.2004. RLTS.T55291A11275223.en). Accessed on 28 Feb 2019.
Bitar, Y.O.C.; Silva, K.R.A.; Filho, H.F.S.; Pinheiro, L.C. 2015. Amphibia, Anura, Hylidae, Cruziohyla craspedopus (Funkhouser, 1957): distribution extension and first record from the state of Pará, Brazil. Check List, 11: 1-3.

Block, J.E.; Unser, S.L.; Mooney, J.K.; Wild, E.R. 2003. Agalychnis craspedopus (Amazon Leaf Frog). Reproduction. Herpetological Review, 34: 134-135.

Fearnside, P. 2005. Deforestation in Brazilian Amazonia: history, rates, and consequences. Conservation Biology, 19: 680-688.

Frost, D.R. 2019. Amphibian species of the world: an online reference. Version 6.0. Electronic database. American Museum of Natural History, New York. (http://research.amnh.org/ herpetology/amphibia/index.html). Accessed on 28 Feb 2019.

Funkhouser, A. 1957. A review of the Neotropical treefrogs of the genus Phyllomedusa. Occasional Papers of the Natural History Museum of Standford University, 5: 1-90.

Gray, A.R. 2018. Review of the genus Cruziohyla (Anura: Phyllomedusidae), with description of a new species. Zootaxa, 4450: 401-426.

Hijmans, R.J. 2019. raster: Geographic data analysis and modeling. R package version 2.8-19. (https:/CRAN.R-project.org/ package=raster). Accessed on 26 Apr 2019.

Hoogmoed, M.S., Cadle, J.E. 1991. Natural history and distribution of Agalychnis craspedopus (Funkhouser, 1957) (Amphibia: Anura: Hylidae). Zoologische Mededelingen, 65: 129-142.

Lima, A.P., Guida, M.L., Hödl, W. 2003. Agalycnhis craspedopus. Distribution. Herpetological Review, 34: 379.

Lima, A.P; Magnusson, W.E.; Menin, M.; Erdtmann, L.K.; Rodrigues, D.J.; Keller, C.; Hödl, W. 2012. Guide to the frogs of Reserva Adolpho Ducke. 2nd ed. INPA, Manaus, 188p.

Lynch, J.D. 2005. Discovery of the richest frog fauna in the world - an exploration of the forests to the north of Leticia. Revista de la Academia Colombiana de Ciencias Exactas, Físicas y Naturales, 29: 581-588.

Meneghelli, D.; Messias, M.R.; Sampaio, P.R.M. 2011. Amphibia, Anura, Hylidae, Cruziohyla craspedopus (Funkhouser, 1957): distribution extension in southwestern Amazonia, state of Rondônia, Brazil. Check List, 7: 811-812.

Moraes, L.J.C.L; Pavan, D. 2017. Another puzzle piece: new record of the Fringed Leaf Frog, Cruziohyla craspedopus (Funkhouser, 1957) (Anura: Phyllomedusidae), in the eastern Amazon rainforest. Check List, 13: 1-4.

Núñez, D; Riera-Vite, T., Orellana, F.; Brito. J. 2015. Upper altitudinal and southern geographic range extensions for Cruziohyla craspedopus (Anura: Hylidae) (Funkhouser, 1957) in Ecuador. Check List, 11: 1-3.

Read, M; Ron, S. 2018. Cruziohyla craspedopus. (https://bioweb. bio/faunaweb/amphibiaweb/FichaEspecie/Cruziohyla\%20 craspedopus). Accessed on 24 Apr 2019.

Rodrigues, D.J.; Lima, M.M.; Kawashita-Ribeiro, R.A. 2011. Amphibia, Anura, Hylidae, Cruziohyla craspedopus (Funkhouser, 1957): distribution extension, new state record and distribution map in Brazil. Check List, 7: 149-150. 
Rodíguez, L.O.; Duellman, W.E. 1994. Guide to the frogs of the Iquitos region, Amazonian Peru. Natural History Museum of the University of Kansas, Lawrence, 114p.

Ruiz-Carranza, P.M.; Ardila-Robayo, M.C.; Lynch, J.D. 1996. Lista actualizada de la fauna de Amphibia de Colombia. Revista de la Academia Colombiana de Ciencias Exactas, Físicas y Naturales, 77: $365-415$.

Sexton, J.O.; Song, X-P.; Feng, M.; Noojipady, P.; Anand, A.; Huang, C.; et al. 2013. Global, 30-m resolution continuous fields of tree cover: Landsat-based rescaling of MODIS Vegetation Continuous Fields with lidar-based estimates of error. International Journal of Digital Earth, 6: 427-458.
Turell, C.; Crnobrna, B.; Smith-Bessen M. 2016. Monitoring a population of Cruziohyla craspedopus (Anura: Hylidae) using an artificial breeding habitat. Amphibian and Reptile Conservation, 10: 1-6.

Venancio, N.M.; de Moura, A.L.B.; Brito, T.F.; de Melo, T.N.; de Souza. 2014. First record of Cruziohyla craspedopus (Anura: Hylidae) for the state of Acre, with an updated distribution map. Herpetology Notes, 7: 479-480.

Wizen, G. 2017. Consecutive breeding in human-made infrastructure by Cruziohyla craspedopus (Funkhouser, 1957) in Ecuador. Herpetology Notes, 10: 721-722.

RECEIVED: $15 / 03 / 2019$

ACCEPTED: 22/05/2019

ASSOCIATE EDITOR: Claudia Keller 